\title{
Acetylcholinesterase inhibition by somes promising Brazilian medicinal plants
}

\author{
Feitosa, CM..$^{a, b *}$, Freitas, RM. ${ }^{a}$, Luz, $_{\text {NNN. }}{ }^{b}$, Bezerra, MZB..$^{c}$ and Trevisan MTS. ${ }^{c}$ \\ aPós-graduação em Ciências Farmacêuticas, Universidade Federal do Piauí - UFPI, \\ CEP 64049-550, Teresina, PI, Brazil

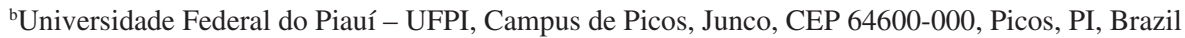 \\ 'Departamento de Química Orgânica e Inorgânica, Universidade Federal do Ceará - UFC, \\ CEP 60021-970, Fortaleza, CE, Brazil \\ *e-mail: chistiane@ufpi.edu.br
}

Received October 5, 2010 - Accepted November 11, 2010 - Distributed August 31, 2011

\begin{abstract}
A microplate assay and a thin-layer chromatography (TLC) "in situ" assay based on the Ellman assay was used to screen for acetylcholinesterase inhibitors from ethyl acetate and methanol extracts of Brazilian medicinal plants of families that, according to the literature, have traditional uses that might be connected with acetylcholinesterase inhibition. Eighteen species belonging to Convolvulaceae, Crassulaceae, Euphorbiaceae, Leguminosae, Malvaceae, Moraceae, Nyctaginaceae and Rutaceae families were tested. The most active plants were Ipomoea asarifolia $\left(\mathrm{IC}_{50}=0.12 \mathrm{mg} / \mathrm{mL}\right)$, Jatropha curcas $\left(\mathrm{IC}_{50}=0.25 \mathrm{mg} / \mathrm{mL}\right)$, Jatropha gossypiifolia $\left(\mathrm{IC}_{50}=0.05 \mathrm{mg} / \mathrm{mL}\right)$, Kalanchoe brasiliensis $\left(\mathrm{IC}_{50}=0.16 \mathrm{mg} / \mathrm{mL}\right)$ and Senna alata $\left(\mathrm{IC}_{50}=0.08 \mathrm{mg} / \mathrm{mL}\right)$. The most promising extracts were the Jatropha gossypiifolia and Senna alata species assuming there were compounds with a similar activity to galanthamine, which should contain about $1 \%$ of an active compound, or if present at lower levels even more active compounds than galanthamine $\left(\mathrm{IC}_{50}=0.37 \mathrm{x} 10^{-3} \mathrm{mg} /\right.$ $\mathrm{mL}$ ) should be present.
\end{abstract}

Keywords: Brazilian medicinal plants, Alzheimer's disease, acetylcholinesterase inhibitors, microplate assay.

\section{Plantas medicinais brasileiras promissoras para inibição da acetilcolinesterase}

\section{Resumo}

Os ensaios de microplaca e cromatografia em camada delgada com base no ensaio de Ellman foram usados para triagem de inibidores da acetilcolinesterase dos extratos acetato de etila e metanol de plantas medicinais brasileiras de famílias que, segundo a literatura, tem usos tradicionais que podem estar relacionadas com a inibição da acetilcolinesterase, enzima associada ao mal de Alzheimer. Dezoito plantas das famílias: Convolvulaceae, Crassulaceae, Euphorbiaceae, Leguminosae, Malvaceae, Moraceae, Nyctaginaceae e Rutaceae foram testadas. As espécies mais ativas foram Ipomoea asarifolia $\left(\mathrm{CI}_{50}=0,12 \mathrm{mg} / \mathrm{mL}\right)$, Jatropha curcas $\left(\mathrm{CI}_{50}=0,25 \mathrm{mg} / \mathrm{mL}\right)$, Jatropha gossypiifolia $\left(\mathrm{CI}_{50}=0,05 \mathrm{mg} / \mathrm{mL}\right)$, Kalanchoe brasiliensis $\left(\mathrm{CI}_{50}=0,16 \mathrm{mg} / \mathrm{mL}\right)$ e Senna alata $\left(\mathrm{CI}_{50}=0,08 \mathrm{mg} / \mathrm{mL}\right)$. Os extratos mais promissores foram os das espécies Jatropha gossypiifolia e Senna alata, assumindo a presença de compostos com atividade semelhante à galantamina que deve conter cerca de $1 \%$ de um composto ativo, ou se presentes em menores níveis ainda mais compostos ativos que a galantamina $\left(\mathrm{CI}_{50}=0,37 \times 10^{-3} \mathrm{mg} / \mathrm{mL}\right)$ devem estar presentes.

Palavras-chave: plantas medicinais brasileiras, doença de Alzheimer, inibidores da acetilcolinesterase, microplaca.

\section{Introduction}

Based on the cholinergic hypothesis, acetylcholinesterase inhibitors (AChEIs) are widely used to treat Alzheimer's disease (Francis et al., 1999). Galanthamine, an alkaloid from plants of the Amaryllidaceae family, is a selective reversible long-acting and competitive acetylcholinesterase inhibitor (AChEI). This compound is considered to be more effective in the treatment of Alzheimer's disease (AD) and to have fewer limitations than physostigmine and tacrine
(Gordon et al., 2000). Many plants have been reported as interesting sources of AChEI (Gupta and Gupta, 1997; Mukherjee et al., 2007; Trevisan et al., 2003).

The synthetic drug tacrine (Cognex) was the first AChEI to be licensed, but its routine use has been largely restricted due to its hepatotoxicity (Watkins et al., 1994). Thus, plants that have demonstrated hepatoprotective activity 
are relevant in terms of searching for novel formulations or compounds for $\mathrm{AD}$ treatment.

Plants that have shown favorable effects in relation to cognitive disorders, including anticholinesterase, antiinflammatory and antioxidant activities or other relevant pharmacological activities are potentially of interest for clinical use for AD. Plants which affect the cholinergic function in the central nervous system (CNS) are particularly relevant in treating AD (Houghton and Howes, 2003). Besides being used as a medicine, AChEIs are a widely used class of insecticides (Finkelstein et al., 2002).

In order to discover novel potential sources for AChEIs, a microplate assay and a TLC assay were used to screen for AChE inhibitory activity in ethyl acetate and methanol extracts from Brazilian medicinal plants (Ellman et al., 1961; Ingkaninan et al., 2001). Eighteen species were screened and the results show that several plants are very interesting candidates for further isolation of AChEIs.

\section{Material and Methods}

All plants were collected in Brazil in the Medicinal Plant Garden of The Federal University of Ceara - Brazil. The voucher specimens were deposited in the Herbarium Prisco Bezerra at the Federal University of Ceara. Eighteen species were tested and they belong to the Convolvulaceae, Crassulaceae, Euphorbiaceae, Leguminosae, Malvaceae, Moraceae, Nyctaginaceae and Rutaceae families. The names of the plants and parts used are shown in Table 1 .

The fresh plants were dried at room temperature and firstly extracted with hexane to remove waxy materials, then extracted subsequently with ethyl acetate and methanol. The solvents were evaporated under reduced pressure. Forty-eight extracts were obtained from leaves, flowers and stems of the plants.

\subsection{Microplate assay}

AChE inhibitory activity was measured using a 96well microplate reader (Ingkaninan et al.; 2000) based on Ellman's method (Ellman et al., 1961). The enzyme hydrolyzes the substrate acetylthiocholine and the thiocholine product reacts with Ellman's reagent (DTNB) to produce 2-nitrobenzoic-5-mercaptothiocholine (thiocholinethionitrobenzoate disulfide) and 5-thio-2-nitrobenzoic acid (thionitrobenzoate), which can be detected at $405 \mathrm{~nm}$. In 96-well plates, $25 \mu \mathrm{L}$ of $15 \mathrm{mM}$ ATCI in water, $125 \mu \mathrm{L}$ of $3 \mathrm{mM}$ DTNB in buffer B and $25 \mu \mathrm{L}$ of the sample were added and the absorbance was measured at $405 \mathrm{~nm}$ every 15 seconds for 10 times. Then, $25 \mu \mathrm{L}$ of $0.22 \mathrm{U} / \mathrm{mL}$ AChE solution was added to the wells and the microplate was read again at the same wavelength 10 times with 15 seconds intervals. The measured increase of absorbance was linear for more than 2 minutes. The velocities of the reactions before and after adding enzymes were calculated using microplate manager software, version 4.0 (Bio-Rad Lab). To calculate the $\mathrm{IC}_{50}$ values, each sample was assayed at four concentrations. After adding the enzyme, the inhibition percentage was calculated comparing the velocities of the sample and the blank $(\mathrm{MeOH})($ Table 1).

\subsection{TLC assay positive and false-positive}

All samples were dissolved in methanol to prepare solutions of $10 \mathrm{mg} / \mathrm{mL}$ and $5 \mathrm{mg} / \mathrm{mL}$. Then, $1.5 \mu \mathrm{L}$ of each sample was spotted on the silica gel TLC plate and developed with chloroform: methanol 9:1 after which the enzyme inhibitory activities were detected using Ellman's method "in situ" on the plate (Ellman et al., 1961; Rhee et al., 2001). The developed plates were sprayed with $1 \mathrm{mM}$ DTNB and $1 \mathrm{mM}$ ATCI in buffer A. It dried for 3-5 minutes, then an enzyme solution of AChE from an electric eel (type VI-s lyophilized, $261 \mathrm{U} / \mathrm{mg}$ solid, $386 \mathrm{U} / \mathrm{mg}$ protein) dissolved in buffer $\mathrm{A}(500 \mathrm{U} / \mathrm{mL}$ stock solution) was diluted with buffer A to obtain $5 \mathrm{U} / \mathrm{mL}$ enzyme and was then sprayed on the plate (Rhee et al., 2001). Yellow backgrounds with white spots for inhibiting compounds were visible after about 5 minutes. These observations must be recorded within 15 minutes because they fade after 20-30 minutes. To observe whether the positive results of the samples in TLC or the microplate assay are due to enzyme inhibition or to the inhibition of the chemical reaction between DTNB and thiocholine, (the product of the enzyme reaction), 5 units/mL of AChE was premixed with $1 \mathrm{mM} \mathrm{ATCI}$ in buffer $\mathrm{A}$ and incubated for 15 minutes at $37^{\circ} \mathrm{C}$. This enzyme-substrate mixture was used as thiocholine spray (Rhee et al., 2001). Samples were spotted on the silica gel TLC plate developed as described above and sprayed with $1 \mathrm{mM}$ solution DTNB followed by the thiocholine spray. White spots on a yellow background were observed for false positive compounds.

\section{Results and Discussions}

\subsection{Plants used in screening and their pharmacological activities}

\section{Convolvulaceae and Crassulaceae}

Ipomoea asarifolia Roem. et Schult and I. batatas Poir are commonly known in the Northeast of Brazil as "batata doce" and "salsa", respectively. The fresh leaves of I. asarifolia are often associated with poisoning cattle, but it can be used as food when dried. Roots of the I. asarifolia are diuretic, emmenagogue and purgative. The literature reports antioxidant actions for I. batatas. Antioxidant activity of plant materials was traditionally attributed to well-known phytochemicals such as alphatocopherol, ascorbic acid, beta-carotene, phenolics and others (Rumbaoa et al., 2009).

Kalanchoe brasiliensis (popularly known as Courama branca) is a Brazilian medicinal plant from the Crassulaceae family, widely used in folk medicine to treat certain chronic inflammatory diseases, such as rheumatism. Koatz et al. (2002) suggested anti-inflammatory and immunosuppressive effects of $K$. brasiliensis. Analgesic and anticonvulsant effects of extracts from the leaves of $K$. crenata (Andrews) Haworth (K. brasiliensis) was shown by Nguelefack et al. (2006). The hydroalcoholic extract from fresh leaves of the 


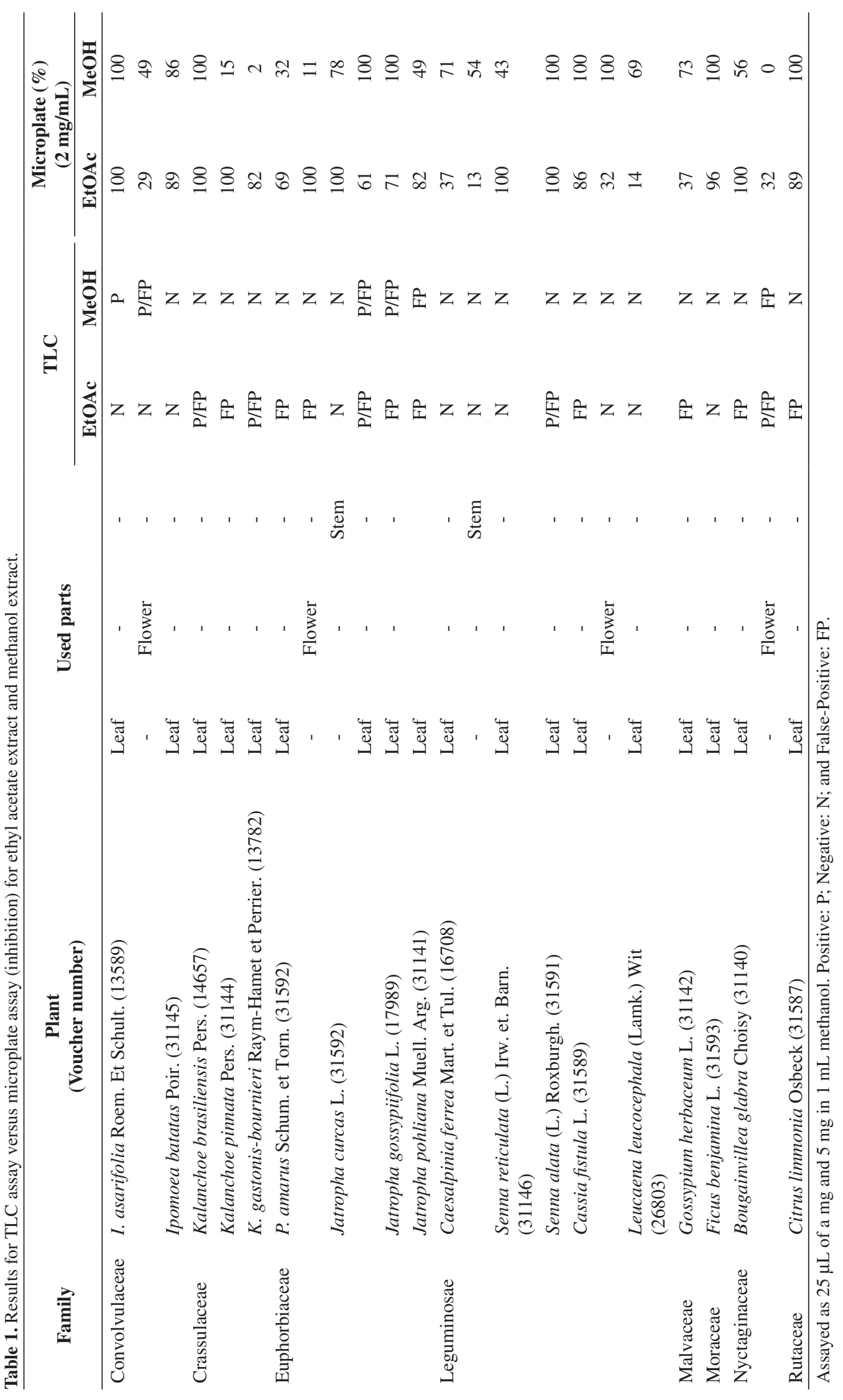


species K. brasilienis demonstrated properties in "in vivo" AChEI in experiments with the isolated abdominal rectus of frogs (Fonteles et al., 1982). Other studies showed the antioxidant activity of the $K$. brasiliensis (Trevisan et al., 2006). This plant is widely used in Brazil's popular medicine as an aqueous extract, and is known to contain many flavonoids (Rossi-Bergmann et al., 1997). Hepatoprotective activity of leaves of Kalanchoe pinnata Pers. (Courama vermelha) is reported by Dixit and Yadav (2003). K. pinnata (Lamarck) Persoon (Bryophyllum pinnatum) is a perennial medicinal herb, popularly used in Brazil and other parts of the world to treat various inflammatory diseases. Previous studies on the chemical composition of $K$. pinnata showed the presence of bufadienolides, terpenoids and flavonoids (Costa et al., 1995). K. gastonis, which is known as "courama comprida", is used to treat various inflammatory diseases and has antioxidant activity. $K$. brasiliensis, $K$. pinnata and $K$. gastonis showed AChEI effects and a toxic effect on Aedes aegypti larvae (Trevisan et al., 2006).

Eufhorbiaceae

In Brazil, the plants of the genus Phyllanthus are popularly known as "quebra pedra," "erva pombinha," and "arrebenta pedra", among others. Reported pharmacological effects of some compounds isolated from some species of Phyllanthus include analgesic, antialergic, antiinflamatory, and antioxidant activity (Karuna et al., 2009). Hepatoprotective activity of $P$. amarus Schum. ethanolic extract was shown in vitro and in vivo studies (Pramyothin et al., 2007).

In Brazil, the plants Jatropha curcas L., Jatropha gossypiifolia L. and Jatropha pohliana Muell. Arg. are popularly known as "pinhão manso," "pião-roxo," and pião-bravo," respectively. In Brazilian folk medicine and in other countries, tea from aerial parts and the roots of various species of Jatropha are used as diuretics, antirheumatics, antiseptics, antidiarrheals, cicatrizants and hypotensives (Villar et al., 1986). Others species of the Euphorbiaceae family were tested using AchE inhibition "in vivo" by Gupta and Gupta, 1997. It should be mentioned that not all the parts of the plant showed AChE activity.

\section{Leguminosae}

In Brazil, Caesalpinia ferrea is popularly known as "pau-ferro". Carvalho et al. (1996) demonstrated preliminary studies of analgesic and anti-inflammatory properties of C. ferrea crude extract. Studies have shown an anti-gastric ulcer effect and anti-inflammatory activity of the aqueous crude extract of $C$. ferrea. The crude extract of $C$. ferrea Mart. contains anthraquinones, alkaloids, depsides, depsidones, flavonoids, lactones, saponins, sugars, tannins, sesquiterpenes and triterpenes. Tannins are regarded as their major components (Souza et al., 2006).

Senna reticulata Willd. is popularly know as "mangerioba grande" and "maria mole". In Brazil, it is used in folk medicine to treat obstructions of the liver and also rheumatism. The phytochemical investigation of Silva et al. (2008) of the wood extracts of S. reticulata yielded six anthraquinones: chrysophanol, physcion, aloeemodin, 1,3,8-trihydroxyanthraquinone, 3-methoxy-1,6,8trihydroxyanthraquinone, emodin and the chrysophanol-10,10' bianthrone. Triterpenes $\alpha$ and $\beta$-amirin, steroids $\beta$-sitosterol and stigmasterol, as well as the flavonoid kaempferol were also identified. Reported uses in various countries of the Senna alata (L.) Roxb. (Cassia alata L.) in ethnopharmacological surveys are: digestive, stomach pains, pre-hepatic jaundice, liver disease, thoracic pain and inflammation. Among others, analgesic and antiinflammatory effects have been reported (Hennebelle et al., 2009). In Brazil, Senna siamea (Syn. Cassia siamea Lamarck) is popularly known as "cássia do sião". The aqueous extract of leaves from the S. siamea species is used in folk medicine to treat insomnia. The anxiolytic activity of the species is attributed to the compound called barakol (Thongsaard et al., 1996). Other species of Cassia spectabilis demonstrated CNS-selective noncompetitive cholinesterase inhibition which was related to the piperidine alkaloid (-)-spectaline isolated from the Cassia spectabilis (Castro et al., 2008).

Leucaena leucocephala, popularly known as leucaena, has been reported to have various medicinal properties ranging from controlling stomach diseases to contraception (Jagan and Azeemoddin, 1988). Dalzell and Mullen (2004) reported a study on the application of pesticides suppressing foliar proanthocyanidin content in Leucaena species. As well as medicine, AChEIs are a widely used class of insecticides (Finkelstein et al., 2002). Cassia occidentalis L., Caesalpinia pulcherrima (L.) SW., Leucaena leucocephala and others species of the genus, were tested using AchE inhibition "in vivo" by Gupta and Gupta (1997). In the plants, it tested positive, however not all parts showed AChE activity.

Malvaceae and Moraceae

Gossypium herbaceum L. (algodoeiro) seeds are reported to have antioxidant activity, antidiarrheic, wound healing, antimigraine, diuretic and dismenorrhea (Narasimha et al., 2008). An hepatoprotective effect of $G$. hirsutum and G. herbaceum extracts is reported by Batur et al. (2008). A "tintura do algodoeiro" is used as a component in a phytotherapeutic agent (Robuterina ${ }^{\circledR}$ ), which is used to treat menstrual cycle disorders. This medicine further includes Berberis vulgaris L., and Gossypium herbaceum L. It also acts as an emmenagogue, hemostatic and ocitocic and has anti-inflammatory activity (Oliveira et al., 2006). Preclinical toxicity of a phytotherapeutic preparation containing Gossypium herbaceum (Cotton Plant) was tested by Mello et al. (2008), whose results revealed the absence of systemic toxicity at a therapeutic dose.

Gossypium herbaceum $\mathrm{L}$ and other species of the Malvaceae family were tested using AchE inhibition "in vivo" acetycholinesterase inhibition by Gupta and Gupta (1997).

Ficus is a genus of about 800 species of woody trees, shrubs and vines in the Moraceae family. Phytochemical investigations of some Ficus species revealed that phenolic compounds constitute the major components. Various papers have reported the presence of antioxidant activity of some Ficus species which is attributed to their phenolic content. Antioxidant activity of Ficus benjamina and others was reported by Abdel-Hameed (2009). Others species 
Table 2. Acetylcholinesterase inhibition on microplate assay.

\begin{tabular}{lccc}
\hline \multicolumn{1}{c}{ Plants } & Used parts & Extract & IC $_{\mathbf{5 0}}{ }^{\mathbf{c}}(\mathbf{m g} / \mathbf{m L})$ \\
\hline Ipomoea asarifolia Roem. Et Schult. & Leaf & $\mathrm{MeOH}$ & 0.12 \\
Jatropha curcas L. & Leaf & $\mathrm{MeOH}$ & 0.25 \\
Jatropha gossypiifolia L. & Leaf & $\mathrm{MeOH}$ & 0.05 \\
Kalanchoe brasiliensis Pers. & Leaf & EtOAc & 0.16 \\
Senna alata (L.) Roxburgh. & Leaf & EtOAc & 0.08 \\
Galanthamine & & & $0.37 \times 10^{-3}$ \\
\hline
\end{tabular}

${ }^{a}$ Expressed the final concentration in the reaction mixture.

such as Ficus benghalensis L., Ficus elastica Roxb., Ficus krishnae C. DC., Ficus racemosa L., Ficus religiosa L. were tested for AchE inhibition "in vivo" by Gupta and Gupta (1997), showing AChE inhibitory activity.

\section{Nyctaginaceae and Rutaceae}

Bougainvillea glabra Choisy is an ornamental plant used in gardens in Brazil, commonly known as "Boungainvile". Antidiarrhoeal, antiulcer and antimicrobial activities of leaves of Bougainvillea glabra Choisy were described by Edwin et al. (2007). Inhibition "in vivo" of the stem and branch of the Bougainvillea glabra and other Nyctaginaceae extracts were tested by Gupta and Gupta (1997), showing AChE inhibitory activity.

Species of the genus Citrus are abundant in flavonoids, essential oil, coumarines and pectins (Kuster and Rocha, 2003). Citrus limonia Osbeck, popularly known as "limão", has a major compound in its essential oil limonene. The essential oil of $C$. limonia has larvicidal activity on Aedes aegypti L. (Furtado et al., 2005). Citrus fruits are known to contain natural antioxidants in oil, pulp, seed and bark. According to Pereira (1996), the methanol extracts of seeds of lemons showed antioxidant activity. C. aurantifolia (Christm.). Swingle were tested by AChE inhibition "in vivo" by Gupta and Gupta (1997), and were tested positive.

In this work, eighteen medicinal plants were collected and different plant parts were extracted with ethyl acetate and methanol. Out of the 48 extracts obtained, 17 showed complete inhibition of $\mathrm{AChE}$ in the microplate test at a concentration of $2 \mathrm{mg} / \mathrm{mL}$. The samples were also tested on TLC plates. In this method, 21 extracts showed activity. However, several of these showed to be false-positive spots only. In several extracts, both positive and false-positive spots were observed. The activity in the microplate and the TLC methods did not always match. This might be due to the different test conditions. The active compounds might bind strongly to silica, resulting in lower activity of the extracts in TLC.

The most active plants in microplate were Ipomoea asarifolia $\left(\mathrm{IC}_{50}=0.12 \mathrm{mg} / \mathrm{mL}\right)$, Jatropha curcas $\left(\mathrm{IC}_{50}=0.25 \mathrm{mg} / \mathrm{mL}\right)$, Jatropha gossypiifolia $\left(\mathrm{IC}_{50}=0.05 \mathrm{mg} /\right.$ $\mathrm{mL})$, Kalanchoe brasiliensis $\left(\mathrm{IC}_{50}=0.16 \mathrm{mg} / \mathrm{mL}\right.$ ) and Senna alata $\left(\mathrm{IC}_{50}=0.08 \mathrm{mg} / \mathrm{mL}\right)$. For extracts that presented strong activity in both tests, the $\mathrm{IC}_{50}$ values were determined (Table 2). Table 2 shows the five species that showed higher inhibition activity, in comparison to commonly used drug galanthamine $\left(\left(\mathrm{IC}_{50}=0.37 \times 10^{-3} \mathrm{mg} / \mathrm{mL}\right)\right.$, which is is considered to be the most effective compound in the treatment of Alzheimer's disease.

Considering that crude extracts are involved, the extracts of Jatropha gossypiifolia and Senna alata seem of interest for further study. Assuming the presence of compounds with a similar activity as galanthamine, they should contain about $1 \%$ of an active compound, or if present at lower levels, even compounds more active than galanthamine $\left(\mathrm{IC}_{50}=0.37 \times 10^{-3} \mathrm{mg} / \mathrm{mL}\right)$ must be present. Plants that have shown favorable effects in relation to cognitive disorders, including anticholinesterase, antiinflammatory and antioxidant activities or other relevant pharmacological activities are potentially of interest to clinical use for Alzheimer's disease.

\section{Conclusions}

Eighteen medicinal plants were screened for inhibitory activity on AchE. The most active plants were Ipomoea asarifolia $\left(\mathrm{IC}_{50}=0.12 \mathrm{mg} / \mathrm{mL}\right)$, Jatropha curcas $\left(\mathrm{IC}_{50}=0.25 \mathrm{mg} / \mathrm{mL}\right)$, Jatropha gossypiifolia $\left(\mathrm{IC}_{50}=0.05 \mathrm{mg} /\right.$ $\mathrm{mL})$, Kalanchoe brasiliensis $\left(\mathrm{IC}_{50}=0.16 \mathrm{mg} / \mathrm{mL}\right)$ and Senna alata $\left(\mathrm{IC}_{50}=0.08 \mathrm{mg} / \mathrm{mL}\right)$. The results show that various plants are very interesting for further isolation of acetylcholinesterase inhibitors, which are widely used in the treatment of Alzheimer's disease.

Acknowledgements - This work was partially supported by grants from the Brazilian National Research Council (CNPq), Brazil. R.M.F and C.M.F. are fellows of CNPq. We would like to thank Dr. Robert Verpoorte, Division of Pharmacognosy, Leiden/Amsterdam Center for Drug Research, Gorlaeus Laboratories, for the correction of the English language and suggestions.

\section{References}

ABDEL-HAMEED, ES., 2009. Total phenolic contents and free radical scavenging activity of certain Egyptian Ficus species leaf samples. Food Chemistry, vol. 114, p. 1271-1277. http://dx.doi. org/10.1016/j.foodchem.2008.11.005

BATUR, M., CHENG, LF., YAN, D. and PARHAT, K., 2008. Hepatoprotective effect of Gossipium hirsutum extract on acute 
experimental hepatitis on rat liver injury. Zhongguo Zhongyao Zazhi, vol. 33, p. 1873-1876.

CARVALHO, JCT., TEIXEIRA, JRM., SOUZA, PJC., BASTOS, JK., SANTOS, FDJ. and SARTI, SJ., 1996. Preliminary studies of analgesic and anti-inflammatory properties of Caesalpinia ferrea crude extract. Journal of Ethnopharmacology, vol. 53, p. 175-178. http://dx.doi.org/10.1016/0378-8741(96)01441-9

CASTRO, NG., COSTA, RS., PIMENTEL, LSB., DANUELLO, A., ROMEIRO, NC., VIEGAS, JRC., BARREIRO, EJ., FRAGA, CAM., BOLZANI., VS and ROCHA, MS., 2008. CNS-selective noncompetitive cholinesterase inhibitors derived from the natural piperidine alkaloid-spectaline. European Journal of Pharmacology, vol. 580, p. 339-349. PMid:18096154. http://dx.doi.org/10.1016/j. ejphar.2007.11.035

COSTA, SS., JOSSANG, A. and BODO, B., 1995. Propriétés biologiques et phytochimie des Kalanchoe. In ALLORGEBOITEAU (Ed.). Kalanchoe (Crassulacées) de Madagascar: Systematique, Ecophysiologie et Phytochimie. p. 219. vol. 1.

DALZELL, SA. and MULLEN, BF., 2004. Application of pesticides suppress foliar proanthocyanidin content in Leucaena species. Animal Feed Science and Technology, vol. 113, p. 191-198. http:// dx.doi.org/10.1016/j.anifeedsci.2003.10.016

DIXIT, VK. and YADAV, NP., 2003. Hepatoprotective activity of leaves of Kalanchoe pinnata Pers. Journal of Ethnopharmacology, vol. 86, p. 197-202. http://dx.doi.org/10.1016/S0378-8741(03)000746

EDWIN, E, SHEEJA, E, TOPPO, E., TIWARI, V. and DUTT, KR., 2007. Anti-diarrhoeal, anti ulcer and antimicrobial activities of leaves of Bougainvillea glabra Choisy. Ars Pharmaceutica, vol. 48, p. 135-144.

ELLMAN, GL, COURTNEY, DK, ANDRES, VJR. and FEATHERSTONE, RM., 1961. A new and rapid colorimetric determination of acetylcholinesterase activity. Biochemical Pharmacology, vol. 7, p. 88-95. http://dx.doi.org/10.1016/00062952(61)90145-9

FINKELSTEIN, BL., BENNER, EA., HENDRIXSON, MC., KRANIS, KT., RAUH, JJ., SETHURAMAN, MR. and McCANN, SF., 2002. Tricyclic Cyanoguanidinas: Synthesis, Site of Action and Inseticidal Activity of Novel Class of Reversible Acetylcholinesterase Inhibitors. Bioorganic and Medicinal Chemistry, vol. 10, p. 599613. http://dx.doi.org/10.1016/S0968-0896(01)00326-1

FRANCIS, PT., PALMER, AM., SNAPE, M. and WILCOCK, GK., 1999. The cholinergic hypothesis of Alzheimer's disease: a review of progress. Journal of Neurology, Neurosurgery and Psychiatry, vol. 66, p. 137-147. PMid:50411. http://dx.doi. org/10.1136/jnnp.66.2.137

FONTELES, MC., CAPELO, RL. and RAO, VSN., 1982. In Anais do VII Simpósio de Plantas Medicinais, 1982. Belo Horizonte.

FURTADO, RL., LIMA, MGA., ANDRADE NETO, M., BEZERRA, NS. and SILVA, MGV., 2005. Atividade larvicida de óleos essenciais contra aedes aegypti (diptera: culicidae). Neotropical Entomology, vol. 34, no 5, p. 843-847.

GORDON, KW., LILIENFELD, S., and GAENS, E., 2000. Efficacy and safety of galanthamine in patients with mild to moderate Alzheimer's disease: multicentre randomized controlled trial. British Medical Journal, vol. 321, p. 1445-1478. PMid:11110737. PMCid:27547. http://dx.doi.org/10.1136/bmj.321.7274.1445
GUPTA, A. and GUPTA, R., 1997. A survey of plants for presence of cholinesterase activity. Phytochemistry, vol. 46, p. 827-831. http://dx.doi.org/10.1016/S0031-9422(97)00393-2

HENNEBELLE, T., WENIGER, B., HENRY, J., SAHPAZ, S. and BAILLEUL, F., 2009. Senna alata. Fitoterapia, vol. 80, p. 385-393. PMid:19446609. http://dx.doi.org/10.1016/j.fitote.2009.05.008

HOUGHTON, PJ. and HOWES, MJR., 2003. Plants used in Chinese and Indian traditional medicine for improvement of memory and cognitive function. Pharmacology Biochemistry and Behavior, vol. 75, p. 513-527.

INGKANINAN, K., DE BEST, CM., VAN DER HEIJDEN, R., HOFTE, AJP., KARABATAK, B., IRTH, H., van DER RHEE, IK., van DE MEENT, M., INGKANINAN, K. and VERPOORTE, R., 2001. Screening for acetylcholinesterase inhibitors from Amaryllidaceae using silica gel thin-layer chromatography in combination with bioactivity staining. Journal of Chromatography $A$, vol. 915, p. 217-223. http://dx.doi.org/10.1016/S00219673(01)00624-0

JAGAN, MRS. and AZEEMODDIN, G., 1988. Recovery of lecithin and refining of subabul (Leucaena leucocephala) seed oil. Journal of Oil Technologists'Association of India, vol. 20, p. 16-17.

KARUNA, R., REDDY, SS., BASKAR, R. and SARALAKUMARI, D., 2009. Antioxidant potential of aqueous extract of Phyllanthus amarus in rats. Indian Journal of Pharmacology, vol. 41, p. 64-67. PMid:20336219. PMCid:2841234. http://dx.doi.org/10.4103/02537613.51342

KOATZ, VLG., IBRAHIM, T., CUNHA, JMT., KALIL, MF. and COSTA, SS., 2002. Immunomodulatory and anti-inflammatory effects of Kalanchoe brasiliensis. International Immunopharmacology, vol. 2, p. 875-883. http://dx.doi.org/10.1016/S1567-5769(02)00020-6

KUSTER, RM. and ROCHA, LM., 2003. Cumarinas, cromonas e xantonas. In SIMÕES, CMO., SHENKEL, EP., GOSMANN, G., MELLO, JCP., MENTZ, LA. and PETROVICK, PR. (Org.). Farmacognosia: da planta ao medicamento. 5nd ed. Porto Alegre: Editora da UFRGS, Florianópolis: Editora da UFSC. p. 247-262.

MELLO, JRB., MELLO, FB., ETGES, RN., HOLLENBACH, C., RODRIGUES, J. and HIRTZ, L., 2008. Toxicidade Pré-Clínica de Fitoterápico Contendo Gossypium herbaceum (Algodoeiro) em Ratos Wistar. Latin American Journal of Pharmacy, vol. 27, p. $46-55$.

MUKHERJEE, PK., VENKATESAN, K., MAINAK, M. and HOUGHTON, PJ., 2007. Acetylcholinesterase inhibitors from plants. Phytomedicine, vol. 14, p. 289-300. PMid:17346955. http://dx.doi.org/10.1016/j.phymed.2007.02.002

NARASIMHA, DK., REDDY, KR., JAYAVEER, KN., BHARATHI, T., VRUSHABENDRA, SWAMY., RAJKUMAR, BM., 2008. Study on the diuretic activity of Gossypium Herbaceum Linn leaves extract in Albino rats. Pharmacologyonline, vol. 1, p. 78-81

NGUELEFACK, TB., NANAB, P., ATSAMOA, AD., DIMOB, T., WATCHO, P., DONGMOC, AB., TAPONDJOU, LA., NJAMENB, D., WANSIA, SL. and KAMANYI, A., 2006. Analgesic and anticonvulsant effects of extracts from the leaves of Kalanchoe crenata (Andrews) Haworth (Crassulaceae). Journal of Ethnopharmacology, vol. 106, p. 70-75. PMid:16423479. http:// dx.doi.org/10.1016/j.jep.2005.12.003

OLIVEIRA, MAC., ALBUQUERQUE, MM., XAVIER, HS., STRATTMANN, RR., GRANGEIRO JÚNIOR, S. and QUEIROZ, AT., 2006. Desenvolvimento e validação de metodologia para quantificação de alcalóides totais como berberina em fitoterápico 
contendo Berberis vulgaris L. Revista Brasileira de Farmacognosia, vol. 16, p. 357-364.

PRAMYOTHIN, P., NGAMTIN, C., POUNGSHOMPOOB, S. and CHAICHANTIPYUTH, C., 2007. Hepatoprotective activity of Phyllanthus amarus Schum. et. Thonn. extract in ethanol treated rats: In vitro and in vivo studies. Journal of Ethnopharmacology, vol. 114, p. 169-173. PMid:17870264. http://dx.doi.org/10.1016/j. jep.2007.07.037

RHEE, KI., VAN RIJN, MR. and VERPOORTE, R., 2001. Qualitative Determination of false-positive effects in acetylcholinesterase assay using thin-layer chromatography. Phytochemical Analalysis, vol. 14, p. 127-131. PMid:12793457. http://dx.doi.org/10.1002/pca.675

ROSSI-BERGMANN, B., COSTA, SS. and MORAES, VLG., 1997. Brazilian medicinal plants: A rich source of immunomodulatory substances. Ciência e Cultura. Journal of the Brazilian Association for the Advancement of Science, vol. 49, p. 395-401.

RUMBAOA, RGO., DJANNA, FC. and GERONIMO, IM., 2009. Phenolic content and antioxidant capacity of Philippine sweet potato (Ipomoea batatas) varieties. Food Chemistry, vol. 113, p. 1133-1138. http://dx.doi.org/10.1016/j.foodchem.2008.08.088

SILVA, MGV., SANTOS, RNS. and BRAZ FILHO, R., 2008. Constituintes químicos do caule de Senna reticulata Willd. (Leguminoseae). Quimica Nova, vol. 31, p.1979-1981.
SOUZA, AB., SOUZA, LMS., CARVALHO, JCT. and MAISTRO, EL., 2006. No clastogenic activity of Caesalpinia ferrea Mart. (Leguminosae) extract on bone marrowcells of Wistar rats. Genetics and Molecular Biology, vol. 29, p. 380-383. http:// dx.doi.org/10.1590/S1415-47572006000200028

THONGSAARD, W., DEACHAPUNYA, C., PONGSAKORN, S., BOYD, EA., BENENNETT, GW. and MARSDEN, CA., 1996. Barakol: A potential anxiolytic extracted from Cassia siamea. Pharmacology Biochemistry and Behavior, vol. 53, p. 753-758. http://dx.doi.org/10.1016/0091-3057(95)02088-8

TREVISAN, MTS., MACEDO, FVV., VAN DE MEENT, M., RHEE, IK. and VERPOORTE, R., 2003. Seleção de Plantas com Atividade Anticolinesterase para Tratamento da Doença de Alzheimer. Quimica Nova, vol. 26, p. 301-304.

TREVISAN, MTS., BEZERRA, MZB., SANTIAGO, GMP., FEITOSA, CM., VERPOORTE, R. and BRAZ FILHO, R., 2006. Larvicides and acetylcholinesterase inhibitors from Kalanchoe species. Química Nova, vol. 29, p. 415-418.

VILLAR, A., PAYA, M. and TERENCIO, MC., 1986. Plants with antihypertensive action. Fitoterapia, vol. 57, p. 131-145.

WATKINS, PB., ZIMMERMAN, HJ., KNAPP, MJ., GRACON, SI. and LEWIS, KW., 1994. Hepatotoxic effects of tacrine administration in patients with Alzheimer's disease. Journal of the American Medical Association, vol. 271, p. 992 - 998. 
